\title{
FAKTOR-FAKTOR KEUANGAN YANG MEMPENGARUHI RATING SUKUK DENGAN MENGGUNAKAN MODEL REGRESI MULTINOMIAL LOGISTIK'
}

\author{
Devi Arum Saputri \\ Mahasiswa Program Studi S1 Ekonomi Islam-Fakultas Ekonomi dan Bisnis-Universitas Airlangga \\ Email: devi.arum-13@feb.unair.ac.id \\ Noven Suprayogi \\ Departemen Ekonomi Syariah-Fakultas Ekonomi dan Bisnis-Universitas Airlangga \\ Email: noven.suprayogi@feb.unair.ac.id
}

\begin{abstract}
ABTRACT:
This research aims to explain the influence of financial performance towards the rate of sukuk listed in Indonesia Stock Exchange in the period of 2013 to 2015. Independent variables used is the ratio of return on assets, current ratio and growth as a proxy for financial performance, and the dependent variable used is sukuk rating. The analytical method used in this study is Multinomial Logistic Regression. The results of this study showed that simultaneous financial performance significantly affect the rating sukuk, and individually there are two models produced.In the first model, the ROA and CR have positive influence on the idA rating compared to the idAAA rating. In the second model, the ROA and CR also have positive influence on the idAA rating compared to the idAAA rating.
\end{abstract}

\section{Keywords: Sukuk, Rating,Financial Peformance, Multinomial Logistic Regression}

\section{PENDAHULUAN}

\section{Latar Belakang}

Sukukmerupakan surat berharga jangka panjang berdasarkan prinsip syariah yang dikeluarkan emiten kepada pemegang sukuk yang mewajibkan emiten untuk membayar pendapatan kepada pemegang sukuk berupa bagi hasil/margin/fee serta membayar kembali dana sukuk pada saat jatuh tempo (Fatwa DSN no: 32/DSN-MUI/IX/2002). Perkembangan sukuk di Indonesia mengalami peningkatan, yang dibuktikan dengan pertumbuhan jumlah sukuk yang telah diterbitkan. Pada bulan Juli 2016 telah mencapai 95 sukuk dengan jumlah 18.692,40 M dan jumlah sukuk yang masih beredar (outstanding) sebanyak 47 sukuk dengan jumlah 10.756 M (OJK,2016). Pertumbuhan penerbitan sukuk menandakan mulai tumbuhnya minat investor terhadap sukuk.

Peraturan Otoritas Jasa Keuangan Nomor 18/POJK.04/2015 tentang penerbitan dan persyaratan sukuk, menjelaskan bahwa setiap perusahaan yang akan menerbitkan sukuk harus melampirkan dokumen hasil peringkat sukuk. Hal tersebut akan menguntungkan bagi pihak investor yang ingin menginvestasikan dananya pada sukuk, karena rating yang diberikan bertujuan untuk melihat kemampuan emiten untuk melunasi kredit (creditworthiness).

Rating merupakan salah satu acuan dari investor ketika memutuskan membeli suatu obligasi (Manurung,2007). Semakin baik rating, maka institusi tersebut dianggap memiliki resiko pengembalian utang paling rendah, sehingga kualitas surat berharga yang diterbitkan semakin

1 Jurnal ini merupakan bagian dari skripsi yang ditulis oleh Devi Arum Saputri, NIM : 04131 1433049, yang diuji pada April 2017 
Saputri, et al/Jurnal Ekonomi Syariah Teori dan Terapan Vol. 5 No. 6 Juni 2018: 433-447; FAKTORFAKTOR KEUANGAN YANG MEMPENGARUHI RATING SUKUK DENGAN MENGGUNAKAN MODEL REGRESI MULTINOMIAL LOGISTIK

baik dan akan semakin diminati oleh investor, yang akan berujung pada biaya pengembalian modal (cost of capital) yang semakin rendah.

Terdapat metodologi rating yang digunakan oleh setiap lembaga pemeringkat dalam memberikan rating. Metodologi rating ini berisi tentang kriteria penilaian yang ditetapkan oleh lembaga sebagai pedoman dalam pemberian rating. Pefindo memberikan kriteria penilaian kepada beberapa bidang, salah satu bidang yaitu corporate atau perusahaan.

\section{Rating Methodology Pefindo}

\begin{tabular}{|l|l|}
\hline \multicolumn{1}{|c|}{ Bidang } & \multicolumn{1}{|c|}{ Kriteria } \\
\hline \multirow{5}{*}{ Corporate } & Industry Risk \\
& Assessment \\
\cline { 2 - 2 } & Bussiness Risk and \\
& Financial Risk \\
& Assessement Support \\
\cline { 2 - 2 } & Parent Rethodology \\
\cline { 2 - 2 } & Goverment Related \\
& Entities (GRE) \\
\hline
\end{tabular}

Sumber: Pefindo,2016.

Penilaian resiko keuangan dalam kriteria Pefindo, erat kaitannya dengan kinerja keuangan perusahaan. Hal tersebut mengingat bahwa penilaian resiko keuangan berdasarkan pada kinerja keuangan perusahaan. Kinerja kevangan perusahaan yang baik dapat meminimalkan resiko-resiko keuangan sehingga meningkatkan rating sukuk perusahaan. Pengukuran kinerja kevangan dapat dilakukan dengan analisis rasio keuangan perusahaan diantaranya terdapat rasio leverage, likuiditas, efisiensi dan profitabiltas.
Menurut Arundina (2015) dalam penelitiannya The Predictive Accuracy of Sukuk Ratings, dihasilkan bahwa rasio kevangan secara keseluruhan mempengaruhi rating sukuk sebesar 96,18\%. Hal tersebut mengindikasikan tingginya pengaruh rasio keuangan terhadap rating sukuk perusahaan. PenelitianArundina, mengggunakan model regresi multinominal logistik dan neurol network. Model regresi multinomial logistik banyak digunakan pada penelitian dimana variabel dependen berupa kategori dimana kategori yang digunakan lebih dari dua. Hasil dari model multinomial logistik memiliki perbedaan dengan regresi lainnya pada jumlah model analisis yang didapat karena adanya pemisahan setiap kategori dan dibandingkan dengan satu kategori yang digunakan sebagai acuan. Sehingga pada model regresi multinomial logistik menghasilkan hasil analisis yang lebih detail setiap kategorinya.

Berdasarkan latar belakang masalah tersebut, peneliti tertarik untuk melakukan penelitian mengenai faktorfaktor yang mempengaruhi prediksi peringkat sukuk dengan menggunakan model regresi multinomial logistik. Penelitian mengenai rating sukuk yang dipengaruhi oleh kinerja keuangan masih jarang dilakukan di Indonesia dan penelitian ini berbeda dengan penelitian yang sebelumnya karena periode yang digunakan lebih baru yaitu 2013-2015. 
Saputri, et al/Jurnal Ekonomi Syariah Teori dan Terapan Vol. 5 No. 6 Juni 2018: 433-447; FAKTORFAKTOR KEUANGAN YANG MEMPENGARUHI RATING SUKUK DENGAN MENGGUNAKAN MODEL REGRESI MULTINOMIAL LOGISTIK

\section{RUMUSAN MASALAH}

Melalui latar belakang di atas maka rumusan masalah yang dapat dibuat adalah:

1. Apakah Profitabilitas berpengaruh terhadap Rating Sukuk?

2. Apakah Likuiditas berpengaruh terhadap Rating Sukuk?

3. Apakah Growth berpengaruh terhadap Rating Sukuk?

4. Apakah Profitabilitas, Likuiditas, dan Growth secara simultan berpengaruh terhadap Rating Sukuk?

5. Apakah Profitabilitas, Likuiditas dan Growth memiliki perbedaan dalam mempengaruhi Rating Sukuk secara parsial?

\section{TUJUAN}

1. Mengetahui pengaruhProfitabilitas terhadap Rating Sukuk.

2. Mengetahui pengaruh Likuiditas terhadap Rating Sukuk.

3. Mengetahui pengaruhGrowth terhadap Rating Sukuk.

4. Mengetahui pengaruh simultan Profitabilitas, Likuiditas, dan Growth terhadap Rating Sukuk.

5. Mengetahui perbedaan pengaruh Profitabilitas, Likuiditas dan Growth terhadap rating sukuk secara parsial.

\section{LANDASAN TEORI}

\section{Teori Sinyal (Signaling Theory)}

Teori sinyal menjelaskan adanya asimetri informasi antara pihak perusahaan dan berbagai pihak yang berkepentingan, berkaitan dengan informasi yang dikeluarkan oleh perusahaan. Asimetri informasi dapat terjadi diantara dua kondisi ekstrem yaitu perbedaan yaitu perbedaan informasi yang kecil sehingga tidak mempengaruhi manajemen, atau perbedaan yang sangat signifikan sehingga dapat berpengaruh terhadap manajemn dan harga saham (Agus, 1996).

Di dalam Islam segala sesuatu diatur, termasuk hubungan sosial yaitu hubungan antar manusia dengan manusia lainnya. Teori sinyal dapat diartikan bahwa setiap orang harus dapat menjaga kepercayaan satu pihak dengan pihak lainnya. Misalkan adanya sifat amanah pada emiten dengan memberikan publikasi laporan-laporan kevangan yang sesuai dengan kondisi perusahaan sebenarnya yaitu tidak dilebih-lebihkan atau dipalsukan. Hal tersebut tentunya akan merugikan bagi banyak pihak, salah satu investor. Di dalam Al Quran dijelaskan mengenai kepercayaan yaitu pasa Surat Al-Anfal 27:

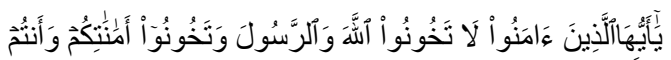

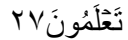
"Hai orang-orang yang beriman, janganlah kamu mengkhianati Allah dan Rasul (Muhammad) dan (juga) janganlah kamu mengkhianati amanat-amanat yang dipercayakan kepadamu, sedang kamu mengetahui"

\section{Sukuk}

Menurut Fatwa Dewan Syariah Nasional-Majelis Ulama Indonesia No. 32/DSN-MUI/XI/2012 mendefinisikan sukuk sebagai surat berharga jangka panjang berdasarkan prinsip syariah yang dikeluarkan emiten kepada pemegang sukuk yang mewajibkan emiten untuk membayar pendapatan kepada 
Saputri, et al/Jurnal Ekonomi Syariah Teori dan Terapan Vol. 5 No. 6 Juni 2018: 433-447; FAKTORFAKTOR KEUANGAN YANG MEMPENGARUHI RATING SUKUK DENGAN MENGGUNAKAN MODEL REGRESI MULTINOMIAL LOGISTIK

pemegang sukuk berupa bagi

Berikut level peringkat sukuk menurut hasil/margin/fee serta membayar kembali dana sukuk pada saat jatuh tempo.

\section{Rating}

Rating merupakan opini yang obyektif untuk menilai kemampuan dan kemauan suatu emiten dalam memenuhi kewajiban finasialnya secara tepat waktu. Rating bukan merupakan rekomendasi untuk membeli, menjual atau menahan suatu obligasi. Rating memberikan indikasi mengenai kemungkinan investor memproleh kembali investasinya sesuai dengan yang dijanjikam, namun tidak memberikan prediksi yang spesifik atas probabilitas terjadinya default (Ifham, 2010:292).

\section{Rating Sukuk}

Sukuk merupakan efek syariah yang memilliki syarat memiliki rating dari lembaga ketika penerbitan.Dari sisi tujuan, rating sukuk sama halnya seperti rating obligasi yakni sebagai indikasi dari keunggulan dan kelemahan efek. Rating sukuk yang diberikan oleh lembaga dapat digunakan oleh investor sebagai salah satu pertimbangan untuk mendanai sukuk. Peratingan pada sukuk dilakukan oleh lembaga pemeringkat efek. Di Indonesia terdapat lembaga pemeringkat efek yang diakui oleh Bank Indonesia yang tercantum dalam Lampiran Surat Edaran Bank Indonesia Nomor 7/8/DPNP tanggal 31 Maret 2005, antara lain Standart and Poor's Ratings, Moody's Indonesia, Fitch Ratings, Kasnic Credit Rating Indonesia dan Pemeringkat Efek Indonesia (Pefindo).

Pefindo:

1. AAA

Efek hutang dengan peringkat AAA merupakan efek hutang denggan peringkat tertinggi dari Pefindo yang didukung oleh kemampuan obligor yang superior relatif dibanding entitas Indonesia lainnya untuk memenuhi kewajibanfinansial jangka panjang sesuai dengan yang diperjanjikan.

2. $\mathrm{AA}$

Efek hutang dengan peringkat $A A$ memiliki kualitas kredit sedikit dibawah peringkat AAA., didukung oleh kemampuan obligor yang sangat kuat untuk memenuhi kewajiban finansial jangka panjangnya sesuai dengan yang diperjanjikan relatif dibandingkan dengan entitas Indonesia lainnya.

3. $A$

Efek hutang dengan peringkat A memiliki dukungan obligor yang kuat dibandingkan dengan entitas Indonesia lainnya untuk memenuhi kewajiban finansial jangka panjangnya sesuai dengan yang diperjanjikan, namun cukup peka terhadap perubahan yang merugikan.

4. $\mathrm{BBB}$

Efek hutang dengan BBB didukung oleh kemampan obligor yang memadairelatif dibandingkan dengan entitas Indonesia lainnya untuk memenuhi kewajiban 
Saputri, et al/Jurnal Ekonomi Syariah Teori dan Terapan Vol. 5 No. 6 Juni 2018: 433-447; FAKTORFAKTOR KEUANGAN YANG MEMPENGARUHI RATING SUKUK DENGAN MENGGUNAKAN MODEL REGRESI MULTINOMIAL LOGISTIK

finansial, namun kemampuan tersebut dapat diperlemah oleh perubahan keadaan bisnis dan perekonomian yang merugikan.

5. $\mathrm{BB}$

Efek hutang dengan peringkat BB menunjukkan dukungan kemampuan obligor yang agak lemah relatif dibandingkan dengan entitas lainnya untuk memenuhi kewajiban finansial jangka panjangnya sesuai dengan yang diperjanjikan, serta peka terhadap keadaan bisnis dan perekonomian yang keadaan bisnis dan perekonomian yang tidak menentu.

6. B

Efek hutang dengan peringkat $B$ menunjukkan parameter perlindungan yangsangat lemah. Meskipun obligor masih memiliki kemampuan untukmemenuhi kewajiban finansial jangka panjangnya, namun adanyaperubahan keadaan bisnis dan perekonomian yang merugikan akan memperburuk kemampuan obligor untuk memenuhi kewajiban finansialnya.

7. $\mathrm{CCC}$

Efek hutang dengan peringkat CCC menunjukkan efek hutang yang tidakmampu lagi memenuhi kewajiban finansialnya, serta hanya tergantungkepada perbaikan keadaan eksternal.
8. D

Efek hutang dengan peringkat $D$ menandakan efek hutang yang macet.

\section{Kinerja Keuangan}

Kinerja keuangan adalah penentuan ukuran-ukuran tertentu yang dapat mengukur keberhasilan suatu organisasi atau perusahaan dalam menghasilkan laba (Sucipto, 2003)

\section{Profitabilitas}

Profitabilitas adalah kemampuan perusahaan memperoleh laba dalam hubungannya dengan penjualan, total aktiva maupun modal sendiri. Profitabilitas ini memberikan gambaran seberapa efektif perusahaan beroperasi sehingga memberikan keuntungan bagi perusahaan. Tingkat profitabilitas yang tinggi dapat mengindikasikan kemampuan perusahaan untuk going concern. Profitabilitas yang tinggi juga dapat menunjukkan kemampuan perusahaan untuk memenuhi kewajibannya. Profitabilitas dapat diukur dengan beberapa rasio yaitu Gross Profit Margin, Net Profit Margin, Basic Earning Power, Earning per Share, Return On Investment, Return on Equity, dan Return on Total Assets.

\section{Likuiditas}

Likuiditas perusahan, menunjukkan kemampuan perusahaan untuk membayar kewajiban jangka pendek tepat pada waktunya. Likuiditas perusahaan ditunjukkan oleh besar kecilnya aset lancar yaitu aset yang mudah untuk diubah menjadi kas yang 
Saputri, et al/Jurnal Ekonomi Syariah Teori dan Terapan Vol. 5 No. 6 Juni 2018: 433-447; FAKTORFAKTOR KEUANGAN YANG MEMPENGARUHI RATING SUKUK DENGAN MENGGUNAKAN MODEL REGRESI MULTINOMIAL LOGISTIK

meliputi kas, surat berharga, piutang,

H5: $\quad$ Profitabilitas, Likuiditas dan Growth persediaan. Dari aset lancar tersebut, persediaan merupakan aset lancar yang paling kurang liquid dibanding dengan yang lainnya. Jadi semakin tinggi rasio likuditas ini berarti semakin besar kemampuan perusahaan untuk memenuhi kewajiban jangka pendeknya. Likuiditas diukur dengan menggunakan beberapa rasio diantara nya adalah Current Ratio, Quick Ratio, dan Cash Ratio.

\section{Growth}

Growth (pertumbuhan perusahaan ) merupakan indikasi yang jelas dimana jika growth positif maka kondisi keuangan perusahaan dalam kondisi baik, dan sebaliknya jika growth negatif maka terjadi masalah dalam keuangan perusahaan. Growth dapat diukur dengan menggunakan penjualan, total aktiva dan laba.

\section{HIPOTESIS PENELITIAN}

Berdasarkan latar belakang, rumusan masalah, tujuan penelitian, landasan teori yang telah dikemukakan, maka hipotesis dalam penelitian adalah:

$\mathrm{Hl}$ : Profitabilitas perusahaan berpengaruh terhadap rating sukuk.

H2: $\quad$ Likuiditas perusahaan berpengaruh terhadap rating sukuk.

H3: Growth perusahaan berpengaruh terhadap rating sukuk.

H4: Profitabilitas, likuiditas dan growth berpengaruh secara simultan terhadap rating sukuk. 
Saputri, et al/Jurnal Ekonomi Syariah Teori dan Terapan Vol. 5 No. 6 Juni 2018: 433-447; FAKTORFAKTOR KEUANGAN YANG MEMPENGARUHI RATING SUKUK DENGAN MENGGUNAKAN MODEL REGRESI MULTINOMIAL LOGISTIK

\section{Growth}

Growth pada penelitian ini adalah growth dari perubahan total asset perusahaan. Semakin besar nilai Growth semakin baik kondisi perusahaan dan sebaliknya.

\section{Jenis dan Sumber Data}

Data yang digunakan dalam penelitian ini adalah data sekunder berupa data rating sukuk dari Pefindo yang masih beredar pada tahun 20132015 dan laporan keuangan perusahaan yang telah diaudit dari website perusahaan.

\section{Populasi dan Sampel}

Populasi dalam penelitian ini adalah seluruh perusahaan yang terdaftar di BEl yang menerbitkan sukuk dan masih beredar pada tahun 2013 hingga 2015 serta memiliki peringkat sukuk di Pefindo. Teknik pengambilan sampel menggunakan purposive sampling.

\section{Teknik Analisis Data}

\section{Regresi Multinomial Logistik}

Model regresi multinomial logistik merupakan perluasan dari binary (dua kategori) logistik yaitu variabel dependennya berbentuk kategori yang lebih dari dua. Variabel dependen yang digunakan pada regresi multinomial logistik, salah satu kategori akan dijadikan references category (kategori pembanding). Kategori ini akan mengurangi satu variabel dependennya, sehingga jika terdapat 3 kategori maka akan terdapat 2 kategori variabel independen yang diuji dibandingkan dengan references category yang ditentukan peneliti. Pemilihan references category pada salah satu variabel adalah hak peneliti yang nantinya akan membedakan hanya pada interpretasi hasil.

Berbeda dengan metode analisis lainnya yang menghasilkan satu model analisis, pada regresi multinomial logistik akan menghasilkan model analisis sebanyak variabel independennya. Jika menggunakan 3 kategori variabel independen, dan salah satu kategori digunakan sebagai references category, maka model analisis yang terbentuk sebanyak 2 model. Berikut model regresi multinomial logistik dengan contoh 3 kategori variabel independen :

$$
\begin{aligned}
& \operatorname{Ln} P_{1} / P_{0}=\beta_{0}+\beta_{1} X_{1}+\beta_{2} X_{2}+\beta_{3} X_{3}+\beta_{p} X_{p} \\
& \operatorname{Ln} P_{2} / P_{0}=\beta_{0}+\beta_{1} X_{1}+\beta_{2} X_{2}+\beta_{3} X_{3}+\beta_{p} X_{p}
\end{aligned}
$$

Dari hasil dua model tersebut terdapat ketentuan (Nachrowi,2002:303) yaitu jika salah satu variabel bebas, misalkan $X_{1}$ nilainya meningkat, maka $L n$ $\mathrm{P}_{1} / \mathrm{P}_{0}$ nilainya meningkat pula. Akan tetapi, hal tersebut tidak berarti nilai $\mathrm{P}_{1}$ juga meningkat. Hal ini tidak terjadi pada model regresi logistik dikotomi (biner), karena bila nilai pembilang $P$ meningkat, maka penyebut $\mathrm{P}-1$ selalu menurun, sehingga P/P-1 meningkat lebih besar lagi.

\section{Uji Hipotesis}

1. Uji Parsial (Uji Wald)

Uji Wald merupakan pengujian terhadap variabel - variabel bebas/independen secara parsial (individu) yang ditunjukkan untuk 
Saputri, et al/Jurnal Ekonomi Syariah Teori dan Terapan Vol. 5 No. 6 Juni 2018: 433-447; FAKTORFAKTOR KEUANGAN YANG MEMPENGARUHI RATING SUKUK DENGAN MENGGUNAKAN MODEL REGRESI MULTINOMIAL LOGISTIK

melihat signifikan dan pengaruh terhadap variabel dependen. Uji Wald pada regresi multinomial logistik melihat tabel Parameter Estimates.

\section{UjiSimultan (UjiG)}

Uji $G$ digunakan untuk melihat apakah ada pengaruh variabel independen secara bersama-sama terhadap variabel dependen. Ujl $G$ pada regresi multinomial logistik dilihat pada hasil sig. Model final pada tabel Model Fitting Information.

3. AnalisisKoefisienDeterminasi $\left(\mathbf{R}^{2}\right)$

Koefisien determinasi

dimaksudkan untuk mengetahui tingkat ketepatan paling baik dalam menganalisis regresi, dimana hal yang ditunjukkan oleh besarnya koefisien determinasi $\left(\mathrm{R}^{2}\right)$. Pada regresi multinomial logistik nilai $\mathrm{R}^{2}$ terdapat 3 nilai, yaitu Cox and Snell, Negelkerke dan McFadden. Nachrowi (2002) menggunakan salah satu dari 3 nilai $R^{2}$ yaitu nilai Negelkerke.

\section{HASIL DAN PEMBAHASAN}

\section{Uji G (Uji Simultan)}

Dalam hasil uji $G$ dapat dilihat pada tabel Model Fitting Information, terlihat bahwa hasil yang didapat adalah signifikan $(p<0,10)$, dan nilai Chi-Square hitung 45,520 lebih besar dibandingkan Chi-Square tabel 10,64 (df=6; $a=0,10)$ maka dari itu dapat disimpulakan $\mathrm{H}_{0}$ ditolak dan $\mathrm{H}_{1}$ diterima yang berarti bahwa secara simultan variabel independen yang terdiri dari ROA, CR dan Growth mempengaruhi rating sukuk dengan nilai signifikan 0,000 dan nilai ChiSquare sebesar 45,520 .

\begin{tabular}{|c|c|c|c|c|}
\hline \multicolumn{5}{|c|}{ Model Fitting Information } \\
\hline \multirow[b]{2}{*}{ Model } & \begin{tabular}{l|} 
Model \\
Fitting \\
Criteria
\end{tabular} & \multicolumn{3}{|c|}{$\begin{array}{c}\text { Likelihood Ratio } \\
\text { Tests }\end{array}$} \\
\hline & $\begin{array}{c}-2 \text { Log } \\
\text { Likelihoo } \\
d\end{array}$ & $\begin{array}{c}\text { Chi- } \\
\text { Squar } \\
e\end{array}$ & Df & Sig. \\
\hline $\begin{array}{l}\text { Interce } \\
\text { pt Only }\end{array}$ & 120.439 & & & \\
\hline Final & 76.812 & 43.626 & & .000 \\
\hline
\end{tabular}

AnalisisKoefisienDeterminasi $\left(\mathbf{R}^{2}\right)$

Pseudo R-Square

\begin{tabular}{|l|c|}
\hline Cox and Snell & .500 \\
Nagelkerke & .586 \\
McFadden & .362 \\
\hline
\end{tabular}

Nilai Pseudo R-Square menjelaskan bahwa sebesar $58,6 \%$ variabel independen ROA, CR dan Growth dapat menjelaskan variabel dependen yaitu rating sukuk. Dengan demikian terdapat $41,4 \%$ yang dijelaskan oleh variabel lain. Hal tersebut dapat terjadi karena banyak faktor lain yang mempengaruhi peringkat. Faktor lain yang mempengaruhi peringkat antara lain resiko industri, posisi pasar dan lingkungan oprasional, arus kas dan fleksibilitas keuangan, arti penting industri/perusahaan bagi pemerintah/perekonomian dan faktor lainnya (www.pefindo.com). Hasil ini cukup baik dari hasil penelitian-peneltian terdahulu yang juga menunjukan $R^{2}$ yang tidak terlalu besar. 
Saputri, et al/Jurnal Ekonomi Syariah Teori dan Terapan Vol. 5 No. 6 Juni 2018: 433-447; FAKTORFAKTOR KEUANGAN YANG MEMPENGARUHI RATING SUKUK DENGAN MENGGUNAKAN MODEL REGRESI MULTINOMIAL LOGISTIK

Uji Wald (Uji Parsial)

\begin{tabular}{|l|l|l|l|l|l|}
\hline RATING & B & Wald & Df & Sig & $\operatorname{Exp(B)}$ \\
\hline idA \\
\hline Intercept & -2.087 & .669 & 1 & .002 & \\
\hline ROA & 24.802 & 12.022 & 1 & .039 & 5.907 \\
\hline CR & 1.976 & .764 & 1 & .010 & 7.211 \\
\hline GR & -1.313 & 1.502 & 1 & .220 & .269 \\
\hline idAA & -2.965 & 11.112 & 1 & .001 & \\
\hline Intercept & -28.940 & 3.741 & 1 & .053 & 3.702 \\
\hline ROA & 2870 & 5.256 & 1 & .022 & 6.490 \\
\hline CR & 1.870 \\
\hline GR & -4.023 & 1.372 & 1 & .241 & .018 \\
\hline
\end{tabular}

References Category is idAAA

Model Persaman Regresi Multinomial Logistik :

$\ln \mathrm{P}_{0} / \mathrm{P}_{2}=-2.087+24.802 \mathrm{ROA}+1.976 \mathrm{CR}-$

$1.313 G R$

$\ln P_{0} / P_{2}=-2.965+28.940 R O A+1.870 C R-$

\subsection{GR}

Bila pada 2 model persamaan regresi multinominal tersebut jika semua variabel bebas dimasukan nilai 0, yang berarti ROA, CR dan Growth, maka akan diperoleh persamaan sebagai berikut pada model pertama dan kedua:

$$
\begin{aligned}
& \operatorname{Ln}\left(P_{0} / P_{2}\right)=-2.087 \\
& \left(P_{0} / P_{2}\right)=\operatorname{Exp}(-0.2087) \\
& \left(P_{0} / P_{2}\right)=0.125 \\
& P_{0}=0.125 P_{2}
\end{aligned}
$$

Hasil tersebut menunjukan arti bahwa peluang ROA, $C R$ dan Growth untuk mendapatkan rating idA lebih rendah 0.125 kali dari peluang mendapatkan rating idAAA.

$$
\begin{aligned}
& \operatorname{Ln}\left(P_{1} / P_{2}\right)=-2.965 \\
& \left(P_{1} / P_{2}\right)=\operatorname{Exp}(-2.965) \\
& \left(P_{1} / P_{2}\right)=0.124
\end{aligned}
$$

$$
P_{1}=0.052 P_{2}
$$

Hasil tersebut menunjukan arti bahwa peluang ROA, CR dan Growth untuk mendapatkan rating idAA lebih rendah 0,052 kali peluang mendapatkan rating idAAA.

Berdasarkan tabel parameter estimates dapat disimpulkan sebagai berikut:

\section{Logit 1 (idA)}

a) Variabel ROA mempengaruhi probabilitas perusahaan mendapatkan rating idA dibandingkan dengan rating idAAA dengan nilai koefisien 24,802 dan signifikan pada $p<0,10$ dengan nilai $\operatorname{Exp}(B) 5,907$.

b) Variabel $C R$ mempengaruhi probabilitas perusahaan mendapat rating idA dibandingkan dengan rating idAAA dengan nilai koefisien 28,940 dan signifikan pada $p<0,10$ dengan nilai $\operatorname{Exp}(B) 7,211$.

C) Variabel Growth tidak mempengaruhi probabilitas perusahaan mendapat rating idA dibandingkan dengan rating idA dengan nilai koefisien -1.313 dan tidak signifikan pada $p>0,10$ dengan nilai $\operatorname{Exp}(B)$ 0,269.

2. Logit 2 (idAA)

a) Variabel ROA mempengaruhi probabilitas perusahaan mendapat rating idAA dibandingkan mendapat rating idAAA dengan nilai koefisien 28,940 dan signifikan pada $p<0,10$ dengan nilai $\operatorname{Exp}(B) 3,702$. 
Saputri, et al/Jurnal Ekonomi Syariah Teori dan Terapan Vol. 5 No. 6 Juni 2018: 433-447; FAKTORFAKTOR KEUANGAN YANG MEMPENGARUHI RATING SUKUK DENGAN MENGGUNAKAN MODEL REGRESI MULTINOMIAL LOGISTIK

b) Variabel CR mempengaruhi probilitas perusahaan mendapat rating idAA dibandingkan mendapat rating idAAA dengan nilai koefisien 1,870 dan signifikan pada $p<0,10$ dengan nilai $\operatorname{Exp}(B)$ 6,490 .

c) Variabel Growth tidak mempengaruhi probabilitas perusahaan mendapat rating idAA dibandingkan mendapat rating idAAA dengan nilai koefisien $-4,023$ dan tidak signifikan pada $p>0,10$ dengan nilai $\operatorname{Exp}(B) 0,018$.

Pengaruh Return on Asset terhadap Rating Sukuk

Berdasarkan hasil diatas, menggambarkan bahwa variabel ROA menjadi ukuran dalam probabilitas perusahaan mendapatkan rating idA dan idAA dibandingkan dengan rating idAAA dan ini bisa terjadi karena ROA merupakan salah satu rasio keuangan dimana besar kecilnya merupakan gambaran dari kemampuan kinerja perusahaan. Semakin besar nilai ROA maka semakin baik pula kinerja perusahaan dikarenakan tingkat pengembalian investasi yang besar.

Perusahaan yang diberikan rating idA, idAA, dan idAAA merupakan perusahaan yang memiliki kemampuan obligor yang kuat, sehingga mampu menjamin atas pembayaran imbalan dan nilai nominal sukuk yang diterbitkan sampai dengan sukuk jatuh tempo. Maka dari itu, perusahaan dengan rating idA, idAA dan idAAA merupakan perusahaan yang mampu mengelola keuangannya termasuk menjamin keuantungan investorinvestornya.

\section{Pengaruh Current Ratio terhadap Rating Sukuk}

Berdasarkan hasil diatas CR menjadi ukuran dalam probabilitas perusahaan mendapatkan rating idA dan idAA jika dibandingkan dengan idAAA dan ini bisa terjadi karena Current Ratio atau rasio likuiditas merupakan rasio yang selaras dengan tujuan pemberian rating perusahaan. Salah satu tujuan utama diberikannya rating sukuk yaitu untuk melihat kemampuan perusahaan melunasi kewajibannya pada saat jatuh tempo (creditworthiness). Perusahaan yang memiliki rating idA, idAA, dan idAAA merupakan perusahaan-perusahaan yang memiliki kualitas kredit yang sudah baik (Lembaga Rating Fitch). Kualitas kredit yang baik memberikan gambaran bahwa perusahaan tersebut mampu mengatasi kredit-kreditnya dan mampu melunasi pada saat jatuh tempo.

\section{Pengaruh Growth terhadap Rating Sukuk}

Berdasarkan hasil olah data, mengindikasikan bahwa Growth tidak menjadi ukuran dalam probabilitas perusahaan mendapatkan rating idA maupun rating idAA dibandingkan dengan idAAA dan ini bisa terjadi karena ukuran perusahaan tidak dapat menjamin secara langsung perusahaan dapat melunasi kewajiban-kewajibannya. Hal tersebut dapat terjadi karena total aset belum dapat mengindikasikan meningkatnya kinerja keuangan secara 
Saputri, et al/Jurnal Ekonomi Syariah Teori dan Terapan Vol. 5 No. 6 Juni 2018: 433-447; FAKTORFAKTOR KEUANGAN YANG MEMPENGARUHI RATING SUKUK DENGAN MENGGUNAKAN MODEL REGRESI MULTINOMIAL LOGISTIK

langsung yang berdampak pada peningkatan rating sukuk. Peningkatan kinerja kevangan akan dapat berpengaruh secara langsung jika dihubungkan dengan pertumbuhan laba perusahaan, karena peningkatan laba merupakan salah satu daya tarik investor terhadap perusahaan. Maka dari itu, perusahaan-perusahaan akan mempertahankan investasinya dengan cara mempertahankan investor dengan meningkatkan pertumbuhan dari segi laba dan penjualannya.

\section{Pengaruh Simultan ROA, CR dan Growth} terhadap Rating Sukuk

Pada tabel Model Fitting Information menunjukan nilai signifikasi sebesar 0,000 (a $<0,10$ ) yang mengartikan bahwa variabel ROA, CR dan Growth berpengaruh signifikan secara simultan terhadap rating sukuk. Hasil perhitungan koefisien untuk menjelaskan seberapa besar pengaruh variabel independen yang dapat menjelaskan variabel dependen yaitu koefisien determinasi atau R-Square, dalam penelitian ini digunakan Negelkerke yaitu sebesar 0,586 tau sebesar 58,6\%. Artinya sebesar $58,6 \%$ perubahan rating sukuk dapat dijelaskan oleh variabel ROA, CR dan Growth, sedangkan sisanya 41,4\% dijelaskan oleh variabel lain diluar ketiga variabel independen yang digunakan dalam penelitian ini.

Perbedaan Pengaruh Profitabilitas,

Likuiditas dan Growth terhadap Rating Sukuk secara Parsial.

Return On Assets merupakan variabel yang berpengaruh signifikan terhadap 
Saputri, et al/Jurnal Ekonomi Syariah Teori dan Terapan Vol. 5 No. 6 Juni 2018: 433-447; FAKTORFAKTOR KEUANGAN YANG MEMPENGARUHI RATING SUKUK DENGAN MENGGUNAKAN MODEL REGRESI MULTINOMIAL LOGISTIK

terhadap rating sukuk. Sehingga Growth

bukan merupakan penialaian lembaga pemeringkat.

\section{SIMPULAN\& SARAN}

Berdasarkan hasil analisis dan interpretasi data yang dilakukan maka dapat diambil kesimpulan sebagai berikut:

1. Pada model pertama, yaitu pada rating idA dibanding pada rating idAAA dapat disimpulkan bahwa variabel ROA dan CR signifikan secara statistik dan memiliki arah koefisien yang positif. Sedangkan variabel Growth tidak signifikan secara statistik dan memiliki arah koefisien yang negatif.

2. Pada model kedua, yaitu pada rating idAA dibanding pada rating idAAA dapat disimpulakan bahwa variabel ROA dan $C R$ signifikan secara statistik dan memiliki arah koefisien yang positif. Sedangkan Growth tidak signifikan secara statistik dan memiliki arah koefisien yang negatif.

3. Hasil perbedaan pengaruh menghasilkan bahwa ROA dan CR lebih banyak berpengaruh terhadap perusahaan yang memiliki rating idA, selanjutnya idAA dan paling sedikit berpengaruh pada perusahaan yang memiliki rating idAAA.

4. Hasil analisis kedua model tersebut memiliki hasil yang sama pada perusahaan-perusahaan yang memiliki rating idA dan idAA serta dibandingkan dengan perusahaan yang memiliki rating idAAA. Akan tetapi hasil yang sama tidak mengindikasikan bahwa perusahaan dengan rating idA sama dengan perusahaan dengan rating idAA, karena setiap rating memiliki nilainya sendiri sesuai dengan kualifikasi masing-masing perusahaan.

Untuk penyempurnaan dan pengembangan ilmu pengetahuan, terdapat saran bagi pihak-pihak yang berkepentingan sebagai berikut:

1. Memperbanyak sampel yang akan digunakan dalam penelitian selanjutnya karena data dalam penelitian ini sangat terbatas.

2. Menambah variabel independen lebih luas lagi, tidak hanya pada kinerja keuangan melainkan pada kinerja non keuangan.

3. Menggunakan variabel Solvabilitas, karena sesuai dengan tujuan rating yaitu untuk menilai kemampuan perusahaan melunasi kreditnya.

4. Menggunakan variabel Growth yang berhubungan langsung dengan peningkatan rating, yaitu Growth pada laba atau pada penjualan.

5. Menambah jangka waktu penelitian menjadi 5 tahun agar data yang digunakan lebih banyak dan hasil lebih baik.

6. Membedakan perusahaan keuangan dan non keuangan pada pengambilan sampel agar dapat mengurangi tingkat kesalahan.

7. Membedakan jenis sukuk yang digunakan untuk diteliti agar hasil analisis yang dihasilkan lebih fokus dan terarah. 
Saputri, et al/Jurnal Ekonomi Syariah Teori dan Terapan Vol. 5 No. 6 Juni 2018: 433-447; FAKTORFAKTOR KEUANGAN YANG MEMPENGARUHI RATING SUKUK DENGAN MENGGUNAKAN MODEL REGRESI MULTINOMIAL LOGISTIK

\section{DAFTAR PUSTAKA}

Afiani, Damalia. 2013. Pengaruh Likuiditas, Produktifitas, Profitabilitas dan Leverage terhadap Peringkat Sukuk. Accounting Analysis Journal, Vol.2 (01).

Arundina, Tika, et al. 2015. The Predictive Accuracy of Sukuk Ratings; Multinomial Logistic and Neural Network Inferences. Jurnal Kevangan, 34.

Asbaugh, Holis, et al. 2004. Corporate Governance and the cost of Equity Capital.Madison.

Askari, Hossein, et al. 2009. New Issues In Islamic Finance and Economics "Progress and Challenges". Asia:John Wiley and Sons (Asia) Pte.ltd.

Brealey, Myres, dan Marcus. 2008. Dasardasar Manajemen Kevangan Perusahaan. Jilid 1. Penerbit Erlangga. Jakarta.

Brigham, Eugene F. And Houston F. Joel. 2009. "Fundamentals of Financial Management" Dasar-dasar Manajemen Keuangan. Edisi 10. Salemba Empat. Jakarta.

Bursa Efek Indonesia. 2016. Data Perusahaan Tercatat. (Sumber: http://www.idx.co.id, diakses pada tanggal 30 Agustus 2016).
Burton, Bruce. 2000. The Determinants of Credit Rating in the United Kingdom Insurance Industry. School of Fnance and Law Working Paper Series no 19.

Djalal, Nachrowi, et al. 2006. Pendekatan Populer dan Praktis Ekonemetrika untuk Analisis Ekonomi dan Keuangan. Jakarta.

Duwi, Priyanto. 2009. 5 Jam Belajar Olah Data dengan SPSS 17. Penerbit Andi. Yogyakarta.

Fatwa Dewan Syari'ah Nasional No: 32/DSN-MUI/XI/2012 Tentang Surat Berharga Jangka Panjang berdasarkan Prinsip Syariah.

Ghozali, Imam. 2005. Aplikasi Analisis Multivariate dengan Program SPSS, Badan Penerbit Universitas Diponegoro, Semarang.

Hariani, Dessy. 2011. Pengaruh Penerapan Good Corporate Governance terhadap Resiko Kreditdan Yield Sukuk ljarah Korporasi. Tesis. Universitas Indonesia.

Ifham, Ahmad. 2010. Buku Pintar Ekonomi Syariah. PT. Gramedia Pustaka Utama. Jakarta.

Iswandi. 2012. Analisis Potensi Kebangkrutan PT. Berlian Laju Tanker, Tbk. Dengan Mengunakan Altman's Z Score. Jurnal Business, Vol 3(2). 
Saputri, et al/Jurnal Ekonomi Syariah Teori dan Terapan Vol. 5 No. 6 Juni 2018: 433-447; FAKTORFAKTOR KEUANGAN YANG MEMPENGARUHI RATING SUKUK DENGAN MENGGUNAKAN MODEL REGRESI MULTINOMIAL LOGISTIK

Jamaldeen, Faleel. 2012. Islamic Finance

For Dummies. Canada: John Wiley and Sons, Inc

Jama'an. 2008. "Teori Manajemen Kevangan Pemasaran, Perbankan dan SDM, 2008, http://ekonomi.kabo.biz/2011/07/† eori-sinyal.html.

Jumingan. 2006. "Analisis Laporan Keuangan". Bumi Aksara. Jakarta.

Kamstra, Mark, et al. 2001.Combining Bond Rating Forecasts Using Logit.The Financial Review.Vol.(37): 75-96.

Kementrian Keuangan Replubik Indonesia. 2012.Laporan Hubungan Dedikasi Investor $2012 . \quad$ (Sumber: http://www.kemkeu.go.id, diakses pada tanggal 30 Agustus 2016).

Maria, Delli. 2014. Pengaruh Mekanisme Corporate Governance dan Profitabilitas Perusahaan terhadap Peringkat Obligasi. Jurnal IImiah ESAI, Vol 8(2).

Manurung, A. H (2007). Pengelolaan Portofolio Obligasi. Elex Media Komputindo. Jakarta.

Nafik, Muhammad. 2009. Bursa Efek Indonesia dan Investasi Syariah. PT. Serambi Ilmu Semesta Jakarta.

Otoritas Jasa Keuangan. 2016. Statistik Pasar Modal Syariah. Direktorat Pasar Modal Syariah.
Pemeringkat Efek Indonesia. 2016. Rating Methodology PEFINDO. (Sumber: http://www.pefindo.com, diakses pada tanggal 30 Agustus 2016).

Pertiwi, Dian Ayu. 2014. Analisis Faktorfaktor yang Mempengaruhi Credit Rating dan Penurunan Credit Rating. Semarang.

Pottier, Steven W. And David W Sommer. 1997. Agency Theory and Life Insurer Ownership Structure. The Journal of Risk and Insurance. Vol. 64. No. 3.

Purwaningsih, Septi. 2013. Faktor yang Mempengaruhi Rating Sukuk yang DitinjaudariFaktorAkuntansidan Non Akuntansi.Accounting Analysis Journal, Vol.2(3).

Putri, Grace. 2010. Analisis Faktor Akuntansi dan Non Akuntansi dalam Memprediksi Peringkat Obligasi Perusahaan Manufaktur. Jurnal Ilmu Administrasi dan Organisasi, Vol.17 (1): 70-78

Quraish, M Shihab. 2002. Tafsir Al Mishbah. Vol 4. Hal 510. Penerbit Lentera Hati.

Raharja \& Sari. 2008. Perbandingan Alat Analisis (Diskriminan \& Regresi Logistik) terhadap Peringkat Obligasi (PT Pefindo). Jurnal Bisnis dan Ekonomi. Vol. 4. No. 1.

Rosyid, Rosmita\&Evina. 2013. Analisis Pengaruh Mekanisme Good 
Saputri, et al/Jurnal Ekonomi Syariah Teori dan Terapan Vol. 5 No. 6 Juni 2018: 433-447; FAKTORFAKTOR KEUANGAN YANG MEMPENGARUHI RATING SUKUK DENGAN MENGGUNAKAN MODEL REGRESI MULTINOMIAL LOGISTIK

Corporate Governance dan

Profitabilitas Perusahaan terhadap

Peringkat Obligasi. Jurnal

Akuntansi UKRIDA, Vol (1).

Saputro, Galih. 2016. Analisis Corporate Governance, Faktor Akuntansi dan Non Akuntansi yang Mempengaruhi Rating Sukuk. Naskah Publikasi. Universitas Muhammadyah Surakarta.

Sartono, Agus. 1996. Manajemen Kevangan Teori dan Aplikasi. Edisi Ketiga. Penerbit BPFE. Yogyakarta.

Shihab, M. Quraish. 2002. Tafsir Al Misbah. Lentera Hati. Vol 4.

Sucipto. 2003. Penilaian Kinerja Keuangan. Universitas Sumatra Utara.

Syed, Salman. 2008. Islamic Capital Markets.Saudi Arabia:Islamic Research and Training Institute, IDB. 